\title{
MMPI Profiles of the Students Who Applied and Won Air Traffic Control and Pilot Training Programs at Anadolu University
}

\author{
Anadolu Üniversitesi Hava Trafik Kontrol ve Pilotaj \\ Programlarına Başvuran ve Kazanan Öğrencilerin MMPI Profilleri
}

\section{Assoc. Prof. Dr. Rüçhan Gökdăg}

\begin{abstract}
Psychological tests special for measuring the fitness of candidates who want to become a pilot haven't been developed yet. Correspondingly MMPI tests have been using for this purpose. In this research MMPI test is administered to 248 candidates who passed the elimination examination for "air traffic control" and "pilot training" departments of Anadolu University, Aviation Vocational High School in the years of 2004, 2005, and 2006. The aim of the study is to compare the students who passed the all examination and those who failed at some point of the examinations according to the 13 sub tests scores taken from MMPI test. According to the result; at the sub tests of PT (psikasteni), Mf (male-female), SC (schizophrenia) and MA (hipo-mania) scores of men are higher than the women.
\end{abstract}

\section{Keywords: $M M P I$, air traffic control, pilot training}

\section{Öz}

Pilot adaylarının mesleğe uygunluğunu belirlemede kullanılabilecek güvenilir psikolojik testler henüz geliştirilmiş değildir. Buna karşıllk MMPI testleri bu amaçla kullanilmaktadır. Bu araştırmada, 2004, 2005 ve 2006 yillarında Anadolu Üniversitesi Havacillk meslek yüksekokulu "hava trafik kontrol" ve "pilotaj" bölümlerinin eleme sinavını geçen 248 adaya MMPI testi uygulanmıştır. Araştırmanın amacı sinavların tamamında başarılı olan öğrenciler ile yapılan sinavların her hangi bir aşamasina başarısız olan öğrencileri MMPI testindeki 13 alt test puanları açısından kıyaslamaktır. Test sonuçlarma göre Pt (psikasteni), Mf (masculinity-femininity) ve Ma (hipomania) alt testlerinde erkeklerin aldığı puanlar kadınlardan yüksek bulunmuştur.

Anahtar Kelimeler: MMPI, hava trafik kontrol, pilotaj

\section{Introduction}

Anatomically speaking, human beings are able to live only on land. However, they have always aspired to fly high in the sky throughout history. According to Greek mythology, the legendary attempts of Deodalus and his son Ikarus to fly ended tragically. This significantly proved the danger and risk of this dream for human beings. Despite the danger and stress it creates, the passion of flying has always existed since the earlier times in history.

The most important risk factor in flying is human; that is pilots. The percentage of the pilots who died during World War I due to enemy attacks and other accidents is only $10 \%$. However, when psychological disorders (panic, suicide etc.) are the factors leading to the death of pilots, this fatality rate increases to 30 (Whitton, 1994: cited by Çetingüç, 1995). Because of high risk of human-related factors in aircraft accidents, the selection of pilot candidates is taken quite seriously all over the world. Despite these attempts, the rate of human-related factors is still about $70 \%$ (Çetingüç, 1995).

In today's world, candidate pilots are evaluated according to various criteria by the experts to determine whether they meet these criteria or not. Physical problems and deficiencies can relatively easily be identified thanks to advanced medical examinations; however, identifying potential psychological disorders or deciding the suitability of a candidate for flights with regard to psychological dimensions is quite difficult (Spohd, 1982; Trump, 1988).

Unfortunately, reliable psychological tests to be used for the decisions regarding the suitability of candidates for pilot training programs have not been de-

Assoc. Prof. Dr. Rüçhan Gökdağ, Anadolu University Faculty of Communicatıon Sciences, rgokdag@anadolu.edu.tr 
veloped yet (Jones, 1985). However, certain tests such as MMPI (Minnesota Multiphasic Personality Inventory) TAT (Thematic Apperception Test), EPQ (Eysenck Personality Questionnaire) are administered to obtain data about the intelligence as well as physical and psychological conditions of the candidate pilots (Çetingüç, 1995).

Anadolu University School of Civil Aviation (SCA) accepts students to its departments according to the results of a "special talent exam". The candidates who get a certain point from national university entrance exam can apply to SCA to be a student. The applicants take a 3-stage exam. In the first stage (pre-assessment stage), candidates are administered certain tests to obtain data about their knowledge, skills and talents. Those who succeed in these tests are given MMPI tests. The second phase involves separate oral exams for the Department of Pilot Training (DPT) and the Department of Air Traffic Control (DATC). The expert who administers and grades MMPI tests is also the jury member in oral exams. Before a student takes the oral exam the expert gives information to the jury about this specific student and the oral exam is structured accordingly. In the last stage of the exam, the candidates who succeed in the oral exam are given the flight tests. Each department admits ten students in total.

The aim of the current study is to reveal whether there are differences between the MMPI test scores of two candidates groups- the group who applied Anadolu University DATC and DPT departments in 2004, 2005 and 2006 and passed the pre-assessment stage but failed in one of the following two stages; and the group that passed all the stages successfully and obtained the right to register to one of the two departments.

The comparison was based on the following dimensions

- Is there a difference between MMPI scales scores of male and female candidates?

- Is there a difference between MMPI scales scores of male and female candidates who obtained the right to register to Department of Pilot Training and those who failed the exams?

- Is there a difference between MMPI scales scores of male and female candidates who obtained the right to register to Department of Air Traffic Control and those who failed the exams?

\section{Method}

The current research is a case study which was carried out with the candidates who applied Anadolu University Department of Pilot Training (DPT) and Department of Air Traffic Control (DATC) and passed the pre-assessment stage. The study compares MMPI scales scores of the candidates who were accepted to these departments and those who failed in the further stages.

\section{Study Population}

The study was conducted with a total of 318 students who applied Anadolu University School of Civil Aviation and passed the pre-assessment stage. Since 70 of these candidates did not answer most of the items in MMPI test, they are excluded from the analysis. So the study realized with 248 candidates.

\section{Data Collection Instrument: Minnesota Multiphasic Personality Inventory (MMPI)}

The Minnesota Multiphasic Personality Inventory (MMPI) is developed in the early 1940s. It's a psychological test that assesses personality traits and psychopathology. The MMPI which is administered in this research has 556 true/false questions. Test items address various issues such as normal personality characteristics, psychiatric symptoms, physical health problems, social attitude, beliefs and judgments, family, education, marriage, gender and occupation. These items are grouped into separate scales according to certain diagnosis groups such as hypochondriasis, depression, hysteria, psychopathic deviate, paranoia, femininity/masculinity, psychasthenia, schizophrenia and hypomania.

MMPI is considered a protected psychological instrument. It can only be given and interpreted by a psychologist trained to do so. After scoring the test results, the psychologist writes up a report interpreting the test results in the context of the person's history and current psychological concerns.

MMPI was translated into Turkish by Işık Savaşır (1981), and scale standardization process was applied to this new version. The book form of the inventory is used in this study.

\section{MMPI Scales}

The standard form of MMPI consists of 13 sub scales: 3 validity scales and 10 clinical scales. These scales are shortly introduced below (Dahlstorm et.al 1972 and Hunsley et al 1988. Cited by Ceyhun and Oral 1998). 


\section{Validity Scales}

MMPI validity scales assess the person's general testtaking attitude and whether they answered the items on the test in a truthful and accurate manner. A person may decide, for whatever reasons, to overreport (exaggerate) or underreport (deny) the behavior being assessed by the test. This data is important in the analysis of the further scales. Validity scales also provide information about personality tendencies and behaviors. There are three validity scales, which are called L, F and K scales. Subjects sometimes do not answer some of the items for several reasons. If there are more than 25-30 items that are not answered, the subject might be considered unreliable for the analysis.

L scale - the L (lie) scale is intended to identify individuals who are deliberately trying to avoid answering the MMPI honestly and in a frank manner. People who make these items are often trying to make themselves look like a better person than they really are. The scale contains 15 items. Test-retest reliability of this scale ranges between .74 and .78 for 1-2 days interval and between .35 and 0.61 for one year interval.

F scale - the F scale is intended to detect unusual or atypical ways of answering the test items, like if a person were to randomly fill out the test. It taps a number of strange thoughts, peculiar experiences, feelings of isolation and alienation, and a number of unlikely or contradictory beliefs, expectations and self-descriptions. If a person answers too many of the F scale items incorrectly, it will invalidate the entire test. The scale contains 60 items. The test consists of 64 items. The increase in F-test scores results in higher score in psychotic scales. Test-retest reliability of this test ranges between .80 and .81 for 1-2 days interval and between .63 and 0.76 for one year interval.

$\mathrm{K}$ scale - the $\mathrm{K}$ scale is designed to identify psychopathology in people who otherwise would have profiles within the normal range. It measures self-control, and family and interpersonal relationships, and people who score highly on this scale are often seen as being defensive. The scale contains 30 items. Testretest reliability of this test ranges between .46 and .56 for 1-2 days interval and between .42 and .72 for one year interval.

\section{Clinical Subscales}

MPI includes 10 clinical subscales, which are a result of answering certain questions on the test in a specific manner. These scales are introduced shortly below (Dahlstorm et.al 1972 and Hunsley et al 1988. Cited by Ceyhun and Oral 1998).

1. Hypochondriasis (Hs) scale - the Hypochondriasis scale tapes a wide variety of vague and nonspecific complaints about bodily functioning. These complaints tend to focus on the abdomen and back, and they persist in the face of negative medical tests. There are two primary factors that this subscale measures poor physical health and gastrointestinal difficulties. The scale contains 32 items. For psychiatric patients, test-retest reliability increased from .79 to 86 in twoweeks period and from .38 to .65 in one-year time. Internal consistency is 0.79 .

2. Depression (D) scale - the Depression scale measures clinical depression, which is characterized by poor morale, lack of hope in the future, and a general dissatisfaction with one's life. The scale contains 57 items. The test-retest reliability was found .78 in 16 different studies conducted with psychiatric patients. Internal consistency was calculated as .81 in 74 studies.

3. Hysteria (Hy) scale - the Hysteria scale primarily measures five components - poor physical health, shyness, cynicism, headaches and neuroticism. The subscale contains 60 items Test-retest reliability of this scale for psychiatric patients ranges between .66 and .80 for $1-2$ weeks interval and between .36 and .72 for one year interval. Internal consistency coefficient was found .78 in 70 studies.

4. Psychopathic Deviate (Pd) scale - the Psychopathic Deviate scale measures general social maladjustment and the absence of strongly pleasant experiences. The items on this scale tap into complaints about family and authority figures in general, self-alienation, social alienation and boredom. The scale contains 50 items. For psychiatric patients, test-retest reliability increased from .69 to .75 in one-two day period and from .48 to .49 in one-year time. Internal consistency is .81 in 71 studies.

5. Masculinity-Femininity (Mf) scale - the Masculinity/Femininity scale measures interests in vocations and hobbies, aesthetic preferences, activity-passivity 
and personal sensitivity. It measures in a general sense how rigidly a person conforms to very stereotypical masculine or feminine roles. The scale contains 56 items. Test-retest correlation for psychiatric phenomena is .79 and .83 in 1-2 days intervals; and .77 and .91 for university students. The correlation for psychiatric patients is .76 and .79 in 1-2 weeks intervals and .72 for male university students. Internal consistency is .73 in 39 studies.

6. Paranoia $(\mathrm{Pa})$ scale - the Paranoia scale primarily measures interpersonal sensitivity, moral selfrighteousness and suspiciousness. Some of the items used to score this scale are clearly psychotic in that they acknowledge the existence of paranoid and delusional thoughts. This scale has 40 items. Test-retest reliability for psychiatric patients is .61 and .71 in 1-2 day intervals and .59 and .65 for one year intervals. Internal consistency is .73.

7. Psychasthenia (Pt) scale - the Psychasthenia scale is intended to measure a person's inability to resist specific actions or thoughts, regardless of their maladaptive nature. "Psychasthenia" is an old term used to describe obsessive-compulsive thoughts and behaviors. This scale also taps into abnormal fears, self-criticisms, difficulties in concentration and guilt feelings. This scale contains 48 items. Test-retest reliability for psychiatric patients is .83 and .86 for $1-2$ week intervals and .48 and .58 for one year intervals. Internal consistency is .73.

8. Schizophrenia (Sc) scale - the Schizophrenia scale measures bizarre thoughts, peculiar perceptions, social alienation, poor familial relationships, difficulties in concentration and impulse control, lack of deep interests, disturbing question of self-worth and self-identity, and sexual difficulties. This scale has 78 items. Test-retest reliability for psychiatric patients is .75 and .82 in 1-2 days intervals and .54 and .94 for one year intervals. Internal consistency is .82 in 73 studies.

9. Hypomania (Ma) scale - the Hypomania scale is intended to measure milder degrees of excitement, characterized by an elated but unstable mood, psychomotor excitement (e.g., shaky hands) and flight of ideas (e.g., an unstoppable string of ideas). The scale taps into over activity - both behaviorally and cognitively - grandiosity, irritability and egocentricity. This scale contains 46 items. Test-retest reliability for psychiatric patients is .71 and .81 in 1-2 day's intervals and .43 and .52 after one year. Internal consistency is .71 in average in 73 different studies.

0. Social Introversion $(\mathrm{Si})$ scale - the Social Introversion scale measures the social introversion and extroversion of a person. A person who is a social introvert is uncomfortable in social interactions and typically withdraws from such interactions whenever possible. They may have limited social skills, or simply prefer to be alone or with a small group of friends. This scale has 69 items. Test-retest reliability for psychiatric patients is .80 and .88 in 1-2 day's intervals and .63 and .64 for one year intervals. Internal consistency is .73.

\section{Calculation of Test Scores}

There is a separate scoring sheet for each scale. The score taken from a test is called "raw score". The raw score a subject takes from $\mathrm{K}$ scale is added to the raw scores of $\mathrm{Hs}, \mathrm{Pd}, \mathrm{Pt}, \mathrm{Sc}$ ve Ma scales at different weights. The final score is the one the subject gets from validity and clinical scales.

The raw scores from each scale are summarized on a separate profile sheet, which have been designed differently for Turkish males and females. There is a standard T score for each clinical scale corresponding to a score in profile. Therefore, the scores from scales are interpreted as "low" or "high" according to this standard $\mathrm{T}$ score. In addition, correlation comments might be made by assessing validity, the relationships among clinical scales, overlaps and discrepancies (Savaşır, 1981).

In the current study, comparisons were based on means scores. A profile was prepared for each table given in "findings and discussions" section by considering the aims of the study and the interpretations were made according to these profiles. The study used Book Form of MMPI. The researcher assessed all 13 scales replied by each student and prepared a profile for each student.

\section{Findings and Discussions}

$220(89 \%)$ of the students that participated in the study was male and $28(11 \%)$ female. $81 \%$ of the students $(n=200)$ applied to "Department of Flight Training". The percentage of female students who applied to this department is $16.5 \%$ and males $84.5 \%$. Half of the females preferred "Department of Flight Training" and the other half "Department of Air Traffic Control". 


\begin{tabular}{|c|c|c|c|c|c|c|c|c|c|c|c|c|c|c|c|}
\hline \multicolumn{6}{|c|}{ men } & \multicolumn{5}{|c|}{ women } & \multicolumn{5}{|c|}{ total } \\
\hline & $\mathrm{N}$ & Min & Max & $\bar{x}$ & $\sigma$ & $\mathrm{N}$ & Min & Max & $\bar{x}$ & $\sigma$ & $\mathrm{N}$ & Min & Max & $\bar{x}$ & $\sigma$ \\
\hline Q & 220 & 0 & 1 & 0,00 & 0,07 & 28 & 0 & 0 & 0,00 & 0,00 & 248 & 0 & 1 & 0,00 & 0,06 \\
\hline $\mathbf{L}$ & 220 & 0 & 13 & 6,88 & 2,97 & 28 & 1 & 10 & 5,71 & 2,00 & 248 & 0 & 13 & 6,75 & 2,90 \\
\hline $\mathbf{F}$ & 220 & 0 & 19 & 4,10 & 2,89 & 28 & 1 & 11 & 3,93 & 2,49 & 248 & 0 & 19 & 4,08 & 2,84 \\
\hline K & 220 & 5 & 25 & 15,83 & 4,13 & 28 & 6 & 20 & 14,43 & 3,27 & 248 & 5 & 25 & 15,67 & 4,06 \\
\hline Hs $+5 \mathrm{~K}$ & 220 & 6 & 23 & 11,65 & 2,59 & 28 & 5 & 19 & 11,21 & 3,10 & 248 & 5 & 23 & 11,60 & 2,64 \\
\hline D & 220 & 6 & 27 & 17,07 & 3,33 & 28 & 2 & 27 & 17,54 & 4,99 & 248 & 2 & 27 & 17,13 & 3,55 \\
\hline Нy & 220 & 8 & 32 & 18,53 & 3,77 & 28 & 8 & 26 & 17,86 & 4,20 & 248 & 8 & 32 & 18,45 & 3,82 \\
\hline$P d+4 K$ & 220 & 6 & 30 & 18,45 & 3,52 & 28 & 12 & 24 & 17,25 & 2,62 & 248 & 6 & 30 & 18,32 & 3,45 \\
\hline Mf & 220 & 8 & 33 & 20,72 & 4,18 & 28 & 19 & 38 & 28,32 & 4,71 & 248 & 8 & 38 & 21,58 & 4,87 \\
\hline $\mathbf{P a}$ & 220 & 1 & 19 & 7,57 & 2,74 & 28 & 3 & 13 & 6,93 & 2,49 & 248 & 1 & 19 & 7,50 & 2,72 \\
\hline$P t+1 K$ & 220 & 13 & 46 & 23,57 & 4,02 & 28 & 16 & 31 & 23,21 & 3,83 & 248 & 13 & 46 & 23,53 & 3,99 \\
\hline $\mathrm{Sc}+1 \mathrm{~K}$ & 220 & 13 & 47 & 22,63 & 4,73 & 28 & 14 & 33 & 21,57 & 4,26 & 248 & 13 & 47 & 22,51 & 4,68 \\
\hline $\mathrm{Ma}+2 \mathrm{~K}$ & 220 & 2 & 36 & 19,34 & 4,49 & 28 & 15 & 31 & 20,68 & 3,04 & 248 & 2 & 36 & 19,49 & 4,36 \\
\hline Si & 220 & 7 & 40 & 17,64 & 5,09 & 28 & 8 & 31 & 17,29 & 5,10 & 248 & 7 & 40 & 17,60 & 5,08 \\
\hline
\end{tabular}

The findings from the tests are presented below in reference to the research questions of the study. For discussion purposes, the researchers referred to the study of Savaşır, I., 1981; Ceyhun ve Oral, 1998 and the following cited references: Dahlstrom, W.G.; Welsch, G.S. 1975; Dahlstrom, W.G.; Welsch, G.S; Dahl Stom, E. 1972; Hathaway, S.R.; McKinley, J.C. 1967; Hunsley, J.; Hathaway, S.R.; McKinley, J.C., 1988

\section{The First Objective: Is There a Difference Between MMPI Scales Scores of Male and Female Candidates?}

The scores from MMPI scales were presented for both sexuality together in Table 1, but the profiles for them made separately and the results which showed significant rise were discussed accordingly.

\section{The Profile Analysis of Males}

According to the Table 1, the findings of validity and clinical results of males are commented below.

\section{The Comments Regarding Validity Scales for Males}

$\mathrm{L}$ scale- pretending to be a good person, the tendency to give socially acceptable answers, excessively traditional and socially adaptable.
K scale- balanced, having higher ego strength, positive self-concept, adaptation, and ability to cope with problems effectively.

\section{The Comments Regarding Clinical Scales for Males}

Si scale- Si scales show that male candidates are optimist, manipulative, superficial, and eccentric. They have impulse control disorder; they want to be together with others; they do not want to be alone; they find it easy to start relationships; they are friendly and curious; they feel the need to be socially accepted and approved.

\section{The Profile Analysis of Females}

According to the figure 2, the findings of validity and clinical results of females are commented like below.

The Comments Regarding Validity Scales for Females F scale - selectiveness, balanced individuals, the tendency to answer only certain items.

K scale - High ego strength, positive self-concept and adaptation, ability to cope with problems. 


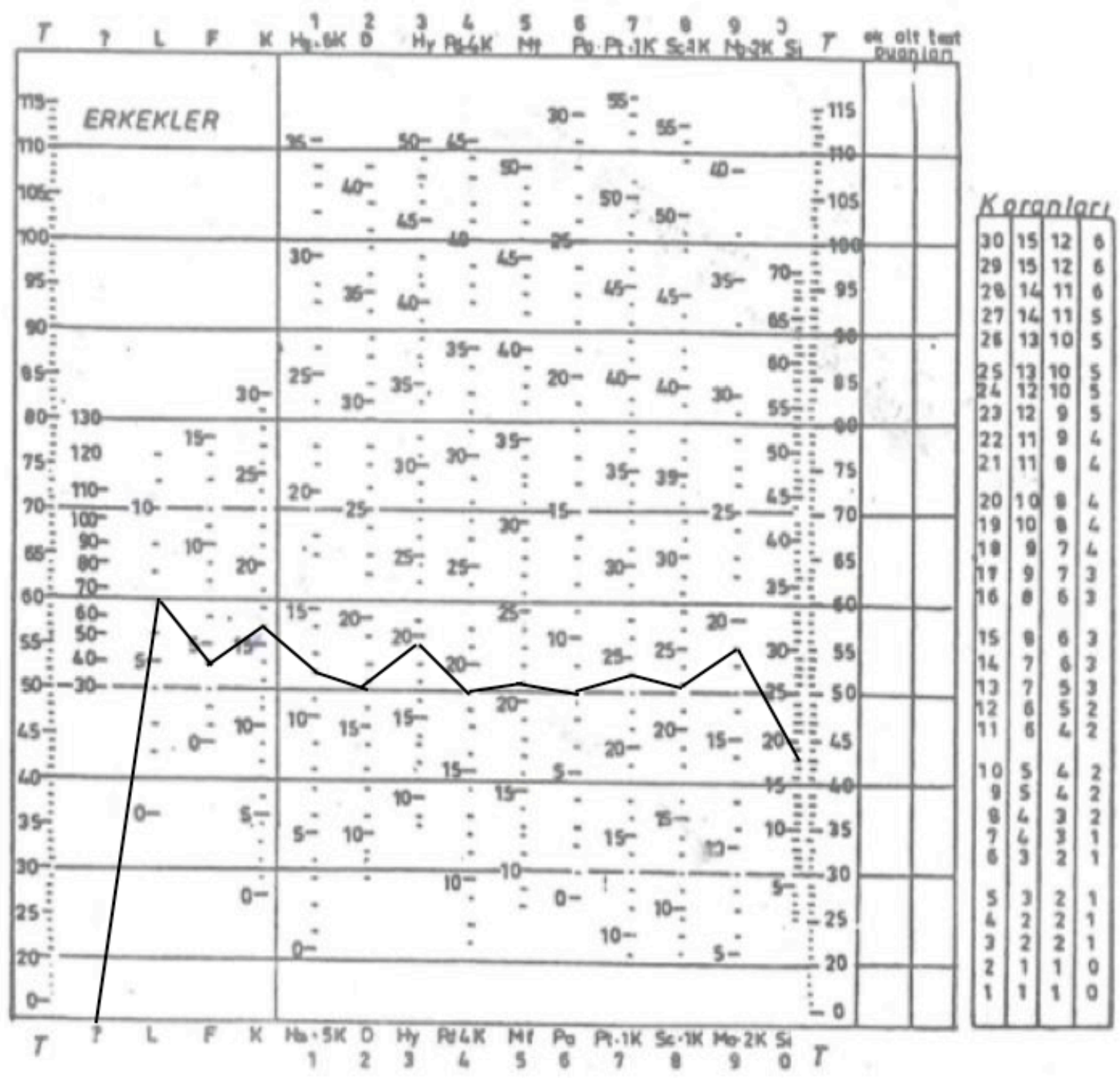

Figure 1. MMPI Scales Profile of Male Candidates 


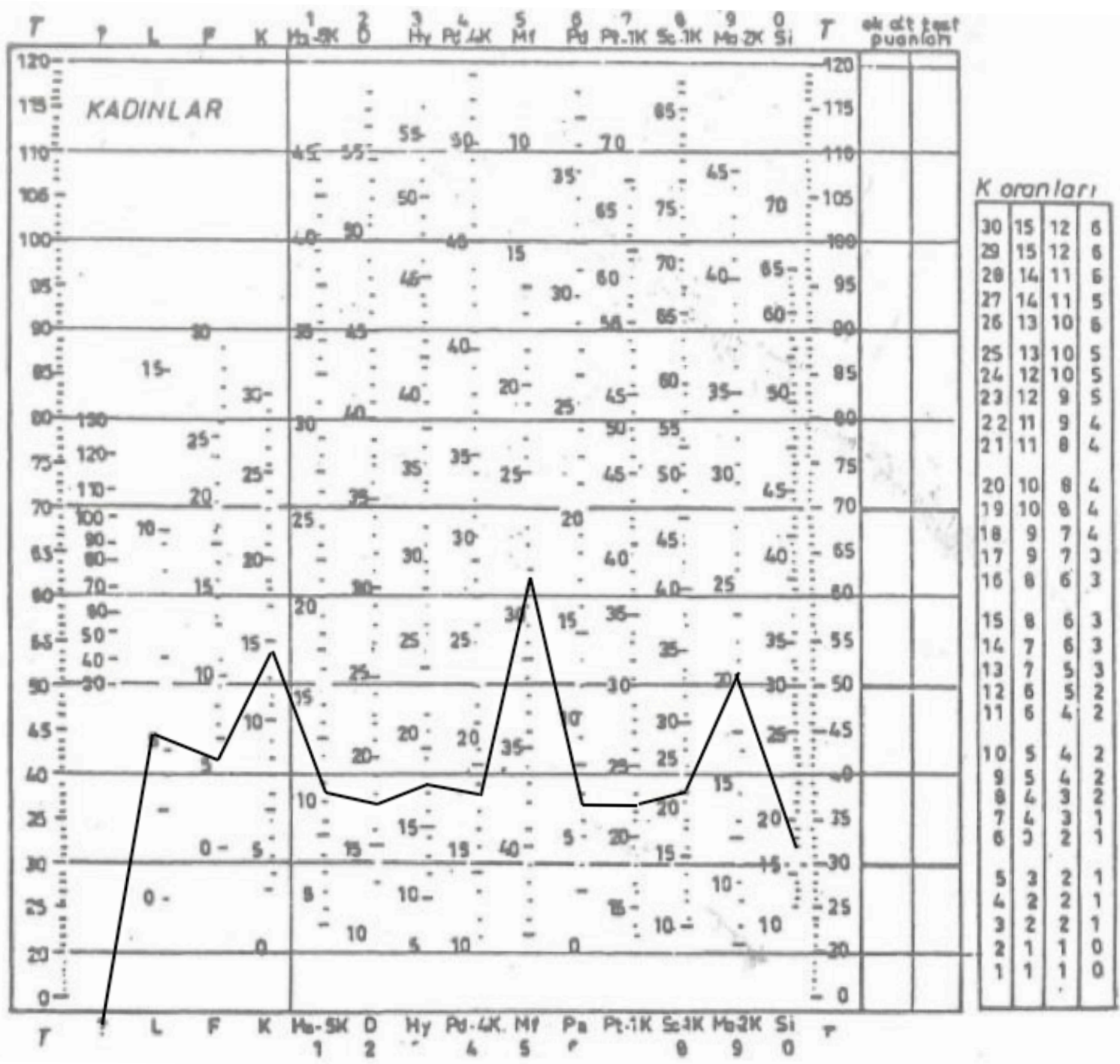

Figure 2. MMPIScales Profile of Female Candidates

\section{The Comment Regarding Clinical Scales for Females}

Mf scale- strong, powerful, aggressive, competitive, stubborn, reluctant to look like and behave like other women, independent, self-confident, spontaneous, dominant, obsessed with carrier and work, choosing masculine sports and occupations, lesbian sexual orientation, the need for self-control in relationships with the opposite sex, low socio-economic level, reflecting different cultural characteristics.

Si scale- optimistic, manipulative, superficial, eccentric, enthusiastic about being with others, starting re- lationships easily, being friendly, curiosity, excessive eagerness to be approved and accepted by the society.

Under the light of the findings mentioned above, it can be said that the tests with similar results for males and females are $\mathrm{K}$ scale in validity scales, and hipomania $(\mathrm{Ma})$ and social introversion $(\mathrm{Si})$ in clinical scales. As for the differences between males and females, $\mathrm{L}$ scale is higher for males and $\mathrm{F}$ scale for females. As for the clinical scales, Hysteria (Hy) is high for males and masculinity-femininity (Mf) for females. 
Table 2. The Highest and Lowest MMPI Scales Scores, Means and Standard Deviation Values of Males Who Obtained the Right to Register Department of Flight Training and those Who Failed to Do So

\begin{tabular}{|c|c|c|c|c|c|c|c|c|c|c|}
\hline \multicolumn{6}{|c|}{ successful } & \multicolumn{5}{|c|}{ unsuccessful } \\
\hline & $\mathrm{N}$ & Min & Max & $\bar{x}$ & $\sigma$ & $\mathrm{N}$ & Min & Max & $\bar{x}$ & $\sigma$ \\
\hline $\mathbf{Q}$ & 50 & 0 & 1 & 0,02 & 0,14 & 137 & 0 & 0 & 0,00 & 0,00 \\
\hline $\mathbf{L}$ & 50 & 2 & 12 & 7,02 & 2,89 & 137 & 0 & 13 & 6,77 & 3,09 \\
\hline $\mathbf{F}$ & 50 & 0 & 13 & 3,78 & 2,53 & 137 & 0 & 14 & 4,05 & 2,82 \\
\hline $\mathbf{K}$ & 50 & 7 & 23 & 16,20 & 4,07 & 137 & 5 & 25 & 15,96 & 4,17 \\
\hline $\mathrm{Hs}+\mathbf{5 K}$ & 50 & 7 & 23 & 11,84 & 2,82 & 137 & 6 & 19 & 11,69 & 2,60 \\
\hline D & 50 & 10 & 23 & 17,06 & 3,15 & 137 & 6 & 27 & 16,91 & 3,45 \\
\hline Нy & 50 & 9 & 25 & 18,86 & 3,59 & 137 & 8 & 32 & 18,54 & 3,86 \\
\hline$P d+4 K$ & 50 & 6 & 27 & 17,94 & 3,62 & 137 & 10 & 27 & 18,52 & 3,31 \\
\hline Mf & 50 & 13 & 29 & 20,70 & 3,61 & 137 & 10 & 33 & 20,65 & 4,07 \\
\hline $\mathbf{P a}$ & 50 & 1 & 13 & 7,00 & 2,70 & 137 & 2 & 19 & 7,71 & 2,69 \\
\hline$P t+1 K$ & 50 & 13 & 46 & 23,00 & 4,91 & 137 & 15 & 37 & 23,55 & 3,70 \\
\hline $\mathrm{Sc}+1 \mathrm{~K}$ & 50 & 13 & 47 & 22,06 & 4,84 & 137 & 13 & 37 & 22,65 & 4,66 \\
\hline $\mathrm{Ma}+2 \mathrm{~K}$ & 50 & 12 & 25 & 18,86 & 3,19 & 137 & 2 & 36 & 19,54 & 4,64 \\
\hline $\mathbf{S i}$ & 50 & 9 & 40 & 17,98 & 5,55 & 137 & 10 & 32 & 17,05 & 4,26 \\
\hline
\end{tabular}

The Second Objective: Is There a Difference Between MMPI Scales Scores of Male and Female Candidates Who Obtained the Right to Register to the Department of Flight Training and Those Who Failed the Exams?

Table 2 shows the MMPI scales scores of male candidates who obtained the right to register to "Department of Flight Training" and those who failed to do so. Scale profiles were prepared (figure 3 ) and discussed accordingly.

\section{The Profile Analysis of Males Who Obtained the Right to Register To the Department}

According to the figure $3 \mathrm{a}$, the findings of validity and clinical tests results of males who obtained the right to register to the department of Flight Training are commented like below.

\section{The Comments of Validity Scales}

When $\mathrm{L}$ and $\mathrm{K}$ scales are considered, individuals seem to pretend to be a good person; there is a tendency to give socially acceptable answers. They are excessively traditional and socially adaptable.

\section{The Comments Regarding Clinical Scales}

Si scale- optimistic, superficial, eccentric, having impulse control disorder, enthusiastic being together with others, not wanting to be alone, starting relationships easily, being friendly, curious, excessive eagerness to be approved by the society.

\section{MMPI Profile Analysis of Males Who Failed to} Obtain the Right to register To the Department

According to the figure $3 \mathrm{~b}$, the findings of validity and clinical tests results of females who failed to obtain the right to register to the department of Flight Training are commented like below.

When validity and clinical scales results of males who failed to obtain the right to register to the department are examined, it is seen that psychopathic deviate $(\mathrm{Pd})$, paranoia $(\mathrm{Pa})$, Psychasthenia $(\mathrm{Pt})$ is one point higher and depression (D) and social introversion (Si) one point lower. However, there is no difference in comments. 

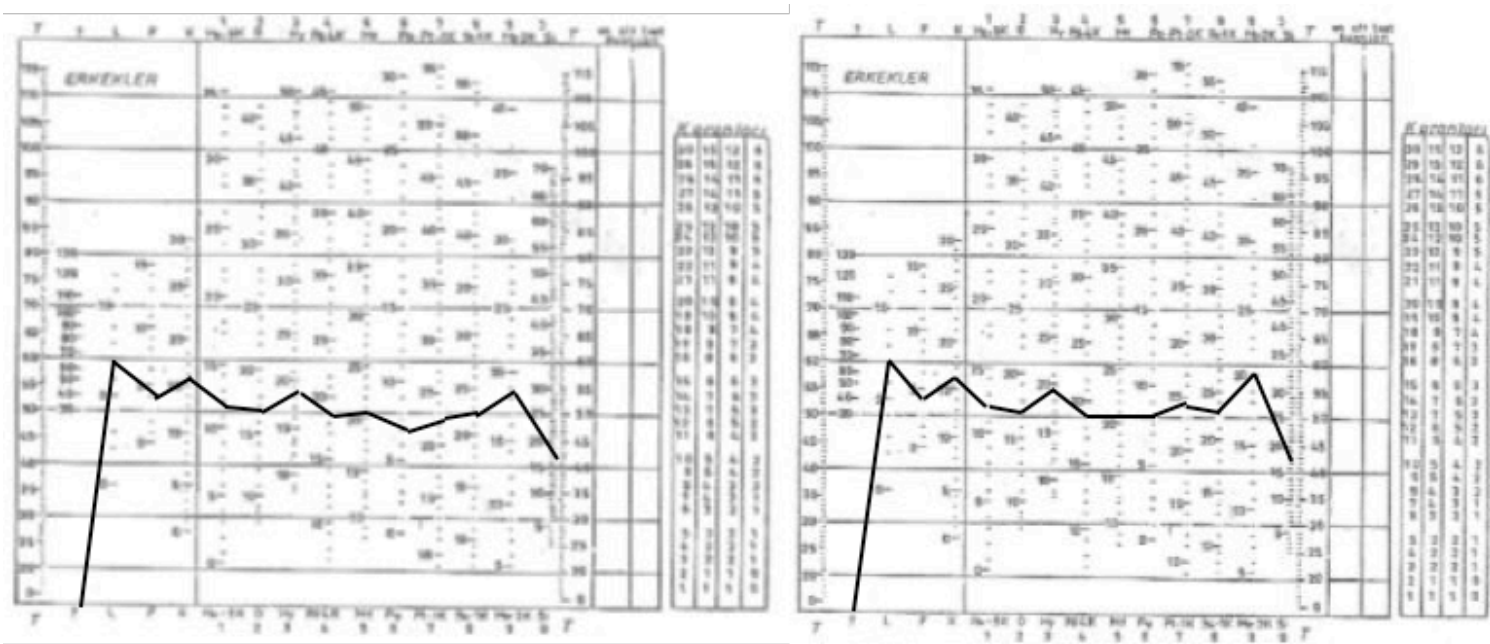

Figure 3. MMPI scales profiles of males who obtained the right to register Department of Flight Training (a) and those who failed to do so (b)

When Figure $3 \mathrm{a}$ and $3 \mathrm{~b}$ take into consideration together; it can be said that there is no difference between males who obtained and failed to obtain the right to register to Department of Flight Training in terms of validity scales. As for the clinical scales psychopathic deviate (Pd), Paranoia (Pa), psychasthenia (Pt) was found to be one point higher; depression (D) and social introversion $(\mathrm{Si})$ one point lower.

\begin{tabular}{|c|c|c|c|c|c|c|c|c|c|c|}
\hline \multicolumn{6}{|c|}{ successful } & \multicolumn{5}{|c|}{ unsuccessful } \\
\hline & $\mathrm{N}$ & Min & Max & $\bar{x}$ & $\sigma$ & $\mathrm{N}$ & Min & Max & $\bar{x}$ & $\sigma$ \\
\hline Q & 4 & 0 & 0 & 0 & 0 & 10 & 0 & 0 & 0 & 0 \\
\hline $\mathbf{L}$ & 4 & 1 & 7 & 4,50 & 2,52 & 10 & 3 & 8 & 5,30 & 1,57 \\
\hline $\mathbf{F}$ & 4 & 1 & 8 & 4,25 & 2,99 & 10 & 1 & 11 & 4,40 & 2,95 \\
\hline $\mathbf{K}$ & 4 & 6 & 19 & 12,00 & 5,72 & 10 & 10 & 18 & 14,70 & 2,58 \\
\hline $\mathrm{Hs}+\mathbf{5 K}$ & 4 & 6 & 14 & 9,75 & 3,50 & 10 & 8 & 19 & 12,30 & 3,09 \\
\hline D & 4 & 12 & 23 & 16,50 & 4,80 & 10 & 2 & 23 & 16,00 & 5,91 \\
\hline Hy & 4 & 9 & 22 & 17,75 & 5,91 & 10 & 15 & 26 & 18,70 & 3,27 \\
\hline$P d+4 K$ & 4 & 12 & 17 & 15,25 & 2,22 & 10 & 15 & 21 & 17,10 & 2,18 \\
\hline Mf & 4 & 19 & 38 & 26,25 & 8,34 & 10 & 22 & 34 & 29,00 & 4,55 \\
\hline $\mathbf{P a}$ & 4 & 4 & 10 & 7,75 & 2,63 & 10 & 3 & 10 & 6,10 & 2,02 \\
\hline$P t+1 K$ & 4 & 16 & 25 & 20,25 & 4,92 & 10 & 18 & 29 & 23,20 & 3,08 \\
\hline $\mathrm{Sc}+1 \mathrm{~K}$ & 4 & 14 & 25 & 18,50 & 5,07 & 10 & 16 & 25 & 20,90 & 2,60 \\
\hline $\mathrm{Ma}+2 \mathrm{~K}$ & 4 & 18 & 21 & 19,50 & 1,29 & 10 & 17 & 25 & 21,20 & 2,30 \\
\hline $\mathbf{S i}$ & 4 & 8 & 18 & 13,50 & 4,20 & 10 & 12 & 31 & 17,80 & 5,47 \\
\hline
\end{tabular}


Table 3 shows the MMPI scales scores of female candidates who obtained the right to register to "Department of Flight Training" and those who failed to do so. Scale profiles were prepared (figure 4 ) and discussed accordingly.

\section{MMPI Profile Analysis of Females Who Obtained the Right to Register To the Department}

According to the figure $4 \mathrm{a}$, the findings of validity and clinical results of females who obtained the right to register to the department of Training are commented like below.

\section{The Comments Regarding Validity Scales}

$\mathrm{K}$ scale- balanced individuals, high ego strength, positive self-concept, adaptation, and the ability to cope with problems.

\section{The Comments Regarding Clinical Scales}

Mf scale- strong, powerful, aggressive, manipulating, competitive, doing activities and works suitable for traditional male role, spontaneous, inhibition in heterosexual relationships, anxious in adopting feminine sexual identity, assertive, stubborn, reluctance to look like and behave like other women, independence in behaviors and thoughts, self-confident, dominant, obsessed with carrier and work, masculine sports and interests, lesbian sexual orientation, control in relationships with opposite sex, fear of losing control in relationships with opposite sex

Si scale- optimistic, manipulative, superficial, eccentric, impulse control disorder, enthusiastic about being with others and reluctance to be alone, starting relationships easily, friendly, curious, excessive eagerness to be approved by society.
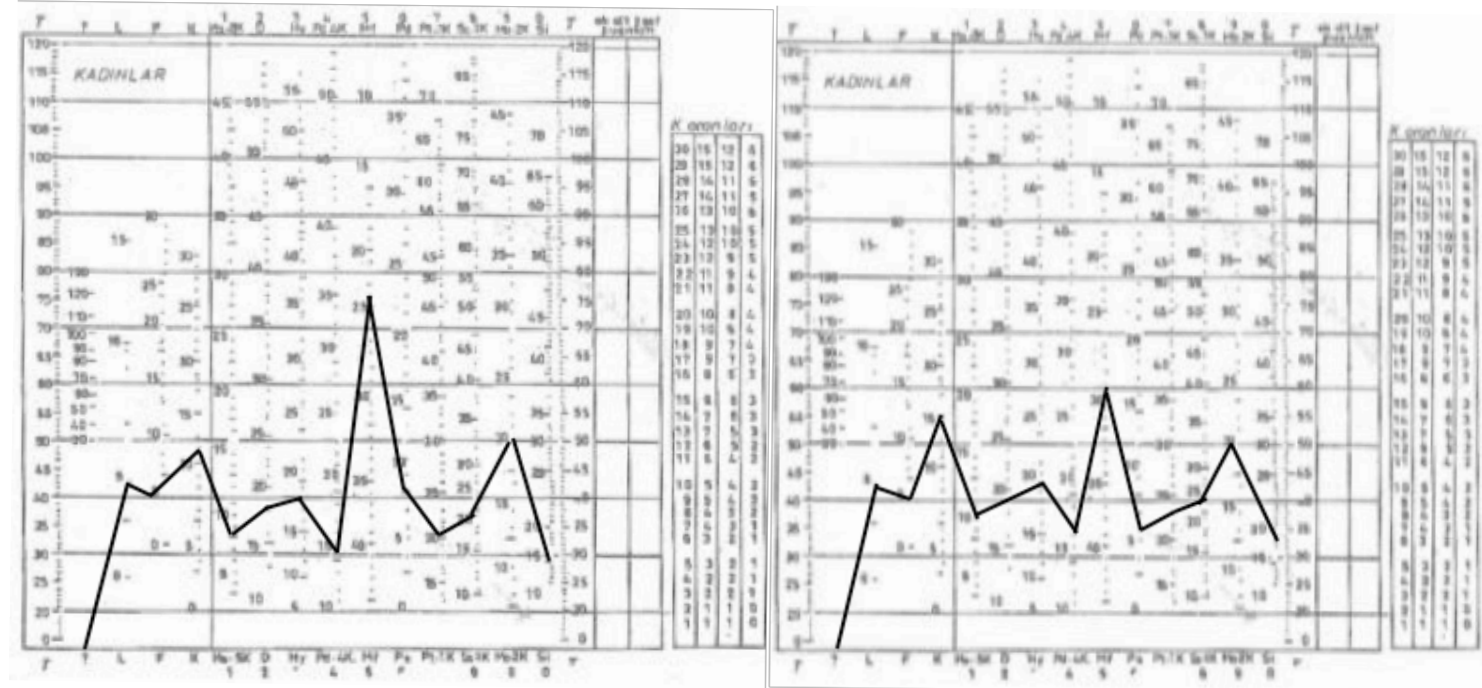

Figure 4. MMPI scales profile of males who obtained the right to register "Department of Air Traffic Control" (a) and those who failed to do so (b)

\section{MMPI Profile Analysis of Females Who Failed To} Obtain the Right to Register To the Department According to the figure 4, the findings of validity and clinical results of females who failed to obtained the right to register to the department of flight Training are commented like below.

Mf scale- active, venturous, competitive and closer to female sexual identity.
For females who obtained the right to register Department of Flight Training and those who failed to do so, $\mathrm{L}$ and $\mathrm{F}$ validity scales are the same but 3 points higher for $\mathrm{K}$ scale. As for clinical scales, hypochondriasis (Hs) was found to be 2 points, hysteria (Hy) 1 point, psychasthenia $(\mathrm{Pt}) 2$ points, masculinity - femininity (Mf) 3 points, 3 points, hypomania (Ma) 1 point and social introversion $(\mathrm{Si}) 4$ points higher while depression (D) is 1 point lower and partanoia 
(Pa) two points lower. However, these differences do not affect the comments made. Only masculinity - femininity (Mf) scale shows a difference in comments, which is about being active, venturous, competitive and closer to female sexual identity.

The Third Objective - Is There a Difference Between MMPI Scales Scores of Male and Female Candidates Who Obtained the Right To Register To "Department of Air Traffic Control" and Those Who Failed To Do So?

Table 4 shows the MMPI scales scores of male candidates who obtained the right to register to "Department of Air Traffic Control" and those who failed to do so. Scale profiles were prepared (figure 5) and discussed accordingly.
MMPI Profile Analysis of Males Who Obtained the Right to Register To the Department

According to the figure $5 \mathrm{a}$, the findings of validity and clinical results of males who obtained the right to register to the department of Air Traffic Control are commented like below.

\section{The Comments Regarding Validity Scales}

L scale- pretending to look good, tendency to give socially accepted answers, being excessively traditional and socially adaptable.

F scale- limited areas of interests, tendency to hide psychopathological problems and nervousness, resistance and pretending to be a good person.

\begin{tabular}{|c|c|c|c|c|c|c|c|c|c|c|}
\hline \multicolumn{6}{|c|}{ successful } & \multicolumn{5}{|c|}{ unsuccessful } \\
\hline & $\mathrm{N}$ & Min & Max & $\bar{x}$ & $\sigma$ & $\mathrm{N}$ & Min & Max & $\bar{x}$ & $\sigma$ \\
\hline $\mathbf{Q}$ & 3 & 0 & 0 & 0,00 & 0,00 & 30 & 0 & 0 & 0,00 & 0,00 \\
\hline $\mathbf{L}$ & 3 & 5 & 10 & 7,67 & 2,52 & 30 & 2 & 12 & 7,07 & 2,68 \\
\hline $\mathbf{F}$ & 3 & 4 & 6 & 5,33 & 1,15 & 30 & 0 & 19 & 4,77 & 3,74 \\
\hline $\mathbf{K}$ & 3 & 11 & 19 & 15,00 & 4,00 & 30 & 6 & 21 & 14,67 & 4,01 \\
\hline $\mathrm{Hs}+5 \mathrm{~K}$ & 3 & 12 & 15 & 13,33 & 1,53 & 30 & 7 & 15 & 11,00 & 2,08 \\
\hline D & 3 & 17 & 23 & 20,67 & 3,21 & 30 & 11 & 26 & 17,47 & 3,04 \\
\hline Hy & 3 & 12 & 24 & 19,67 & 6,66 & 30 & 11 & 23 & 17,80 & 3,41 \\
\hline$P d+4 K$ & 3 & 12 & 17 & 14,67 & 2,52 & 30 & 12 & 30 & 19,40 & 4,12 \\
\hline Mf & 3 & 11 & 24 & 19,67 & 7,51 & 30 & 8 & 31 & 21,20 & 5,28 \\
\hline $\mathbf{P a}$ & 3 & 3 & 9 & 6,67 & 3,21 & 30 & 4 & 17 & 8,00 & 2,97 \\
\hline$P t+1 K$ & 3 & 16 & 27 & 21,67 & 5,51 & 30 & 17 & 32 & 24,83 & 3,50 \\
\hline $\mathrm{Sc}+1 \mathrm{~K}$ & 3 & 20 & 29 & 24,67 & 4,51 & 30 & 17 & 42 & 23,27 & 4,95 \\
\hline $\mathrm{Ma}+2 \mathrm{~K}$ & 3 & 15 & 19 & 17,33 & 2,08 & 30 & 5 & 31 & 19,43 & 5,69 \\
\hline $\mathbf{S i}$ & 3 & 7 & 31 & 19,00 & 12,00 & 30 & 9 & 35 & 19,60 & 6,54 \\
\hline
\end{tabular}

K scale- balanced, high ego strength, positive selfconcept, effective strategies to cope with problems.

\section{The Comments Regarding Clinical Scales}

$\mathrm{D}$ scale- individual establishes a balance between optimism and pessimism in his/her life.

Pd scale- static, passive, not venturous, dependent on social traditions, rigid, not having frequent sexual intercourse.
Sc scale- friendly, cheerful, sensitive, trustworthy, balanced, adaptable, responsible, dependent, conservative, avoiding serious love relationships, obedience to authority, meek, cautious, traditional, lack of imagination, practical, concrete reasoning, hunting for success, status and power, avoiding competition.

S scale- successful in social relationships. 


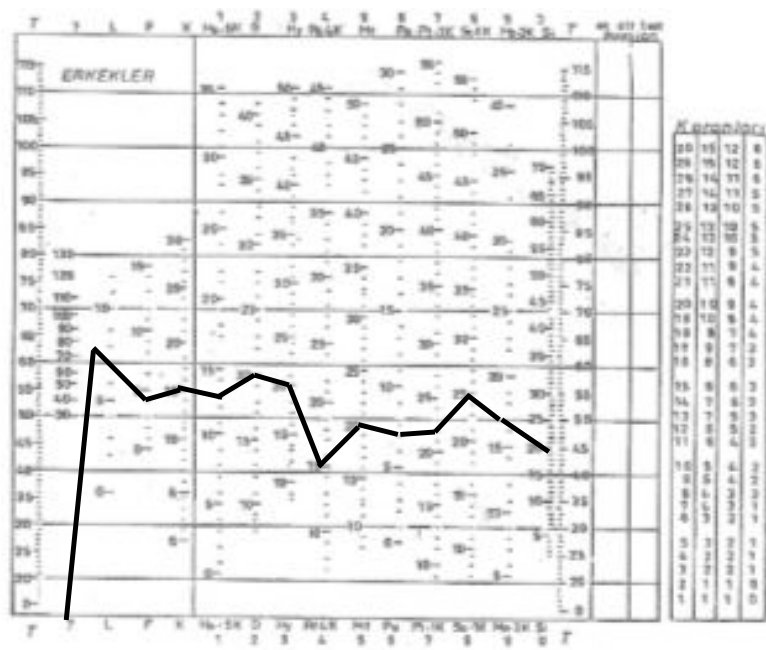

$\mathrm{b}$

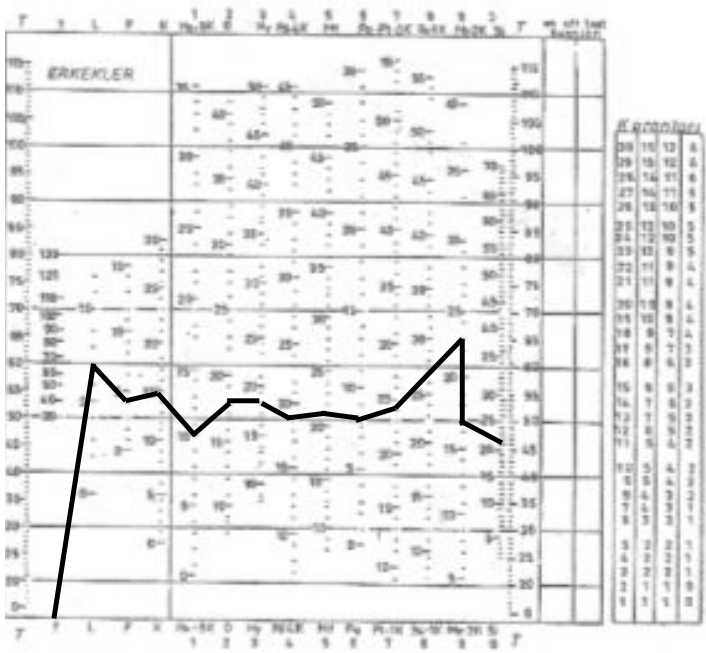

Figure 5. MMPI Scales Profile of Males Who Obtained the Right To Register "Department of Air Traffic Control" (a) and Those Who Failed To Do So (b)

\section{MMPI Profile Analysis of Males Who Failed To} Obtain the Right to Register To the Department According to the figure $5 \mathrm{~b}$, the findings of validity and clinical tests results of males who failed to obtain the right to register to the department of Air Traffic Control are commented like below.

\section{The Comments Regarding Validity Scales}

The comments are the same as of those who obtained the right to register to the department.

\section{The Comments Regarding Clinical Scales}

Although most of the scales are interpreted in the same way, the comment in psychopathic deviate $(\mathrm{Pd})$ scale stating "excessive control, not restricted and partial adaption to social rule" is different.

Table 5 shows the MMPI scales scores of female candidates who obtained the right to register to "Department of Air Traffic Control" and those who failed to do so. Scale profiles were prepared (figure 6) and discussed accordingly.

\section{MMPI Profile Analysis of Males Who Obtained the Right to Register To the Department}

According to the figure $5 \mathrm{a}$, the findings of validity and clinical results of females who obtained the right to register to the department of Air Traffic Control are commented like below.

\section{The Comments Regarding Validity Scales}

F scale- answering the items about certain problem areas, selectiveness, assuming roles effectively in finding solutions to personal problems.

K scale- Balanced individuals, high ego strength, positive self-concept, ability to cope with problems.

\section{The Comments Regarding Clinical Scales}

Si scale- optimistic, manipulative, superficial, crazy and possibility to have impulse control disorder, wanting to be with others and reluctant to be alone, excessively eager to be approved and accepted by the society.

\section{MMPI Profile Analysis of Females Who Failed To} Obtain the Right to Register To the Department According to the figure $5 \mathrm{~b}$, the findings of validity and clinical tests results of females who failed to obtain the right to register to the department of air traffic control are commented like below.

\section{The Comments Regarding Validity Scales}

The results of the validity scales are the same as of those females who obtained the right to register to the department for scales $\mathrm{F}$ and $\mathrm{K}$. 


\begin{tabular}{|c|c|c|c|c|c|c|c|c|c|c|}
\hline \multicolumn{6}{|c|}{ successful } & \multicolumn{5}{|c|}{ unsuccessful } \\
\hline & $\mathrm{N}$ & Min & Max & $\bar{x}$ & $\sigma$ & $\mathrm{N}$ & Min & Max & $\bar{x}$ & $\sigma$ \\
\hline $\mathbf{Q}$ & 3 & 0 & 0 & 0,00 & 0,00 & 11 & 0 & 0 & 0,00 & 0,00 \\
\hline $\mathbf{L}$ & 3 & 2 & 5 & 4,00 & 1,73 & 11 & 5 & 10 & 7,00 & 1,61 \\
\hline $\mathbf{F}$ & 3 & 4 & 8 & 6,00 & 2,00 & 11 & 1 & 5 & 2,82 & 1,60 \\
\hline $\mathbf{K}$ & 3 & 12 & 17 & 13,67 & 2,89 & 11 & 9 & 20 & 15,27 & 2,83 \\
\hline $\mathrm{Hs}+5 \mathrm{~K}$ & 3 & 8 & 12 & 10,00 & 2,00 & 11 & 5 & 16 & 11,09 & 3,21 \\
\hline D & 3 & 16 & 27 & 20,67 & 5,69 & 11 & 12 & 25 & 18,45 & 3,96 \\
\hline Нy & 3 & 17 & 24 & 19,33 & 4,04 & 11 & 8 & 24 & 16,73 & 4,63 \\
\hline$P d+4 K$ & 3 & 16 & 23 & 19,00 & 3,61 & 11 & 14 & 24 & 17,64 & 2,73 \\
\hline Mf & 3 & 22 & 35 & 29,33 & 6,66 & 11 & 23 & 35 & 28,18 & 2,99 \\
\hline $\mathbf{P a}$ & 3 & 8 & 13 & 10,00 & 2,65 & 11 & 3 & 11 & 6,55 & 2,38 \\
\hline$P t+1 K$ & 3 & 23 & 31 & 27,67 & 4,16 & 11 & 18 & 29 & 23,09 & 3,30 \\
\hline $\mathrm{Sc}+1 \mathrm{~K}$ & 3 & 18 & 33 & 24,67 & 7,64 & 11 & 18 & 33 & 22,45 & 3,96 \\
\hline $\mathrm{Ma}+2 \mathrm{~K}$ & 3 & 18 & 31 & 23,00 & 7,00 & 11 & 15 & 24 & 20,00 & 2,65 \\
\hline $\mathbf{S i}$ & 3 & 14 & 16 & 15,00 & 1,00 & 11 & 13 & 31 & 18,82 & 5,25 \\
\hline
\end{tabular}

Table 5. The highest and lowest MMPI scales scores, means and standard deviation values of females who obtained the right to register "Department of Air Traffic Control" and those who failed to do so
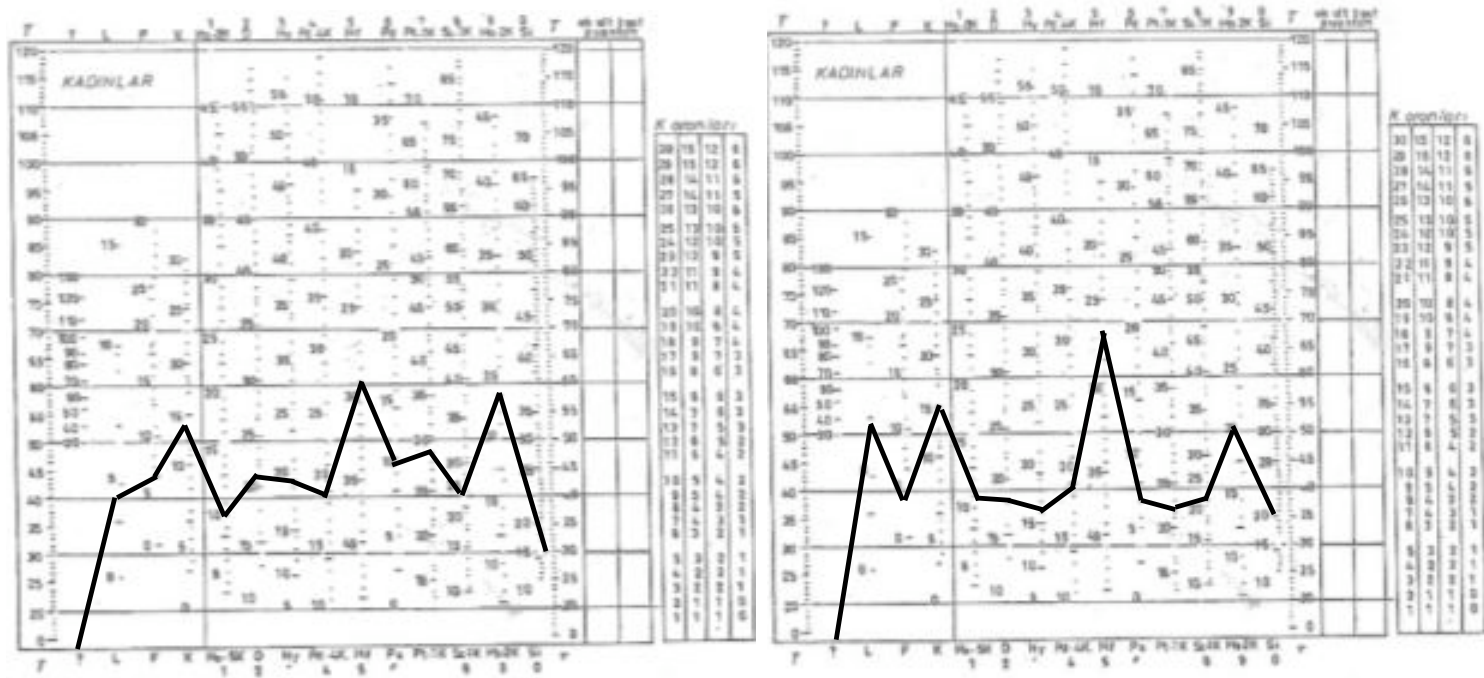

Figure 6. MMPI scales profile of females who obtained the right to register "Department of Air Traffic Control" (a) and those who failed to do so (b) 


\section{The Comments Regarding Clinical Scales}

Mf scale- strong, powerful, aggressive, manipulating, competitive, doing activities and works suitable for traditional male roles, spontaneous, inhibition in heterosexual relationships, lack of adaptation to feminine sexual identity, assertive, stubborn, reluctance to look like or behave like other women, independent, spontaneous, dominant, obsessed with carrier and work, masculine sports, lesbian sexual orientation, excessive control in relationships with opposite sex, and fear of losing control.

\section{Last Words}

When above mentioned results are considered all together, the validity scale findings are the same for those who obtained and failed to obtain the right to register to both departments. As for clinical tests, most of the scales have similar results; only males differed in psychasthenia (Pt) scale, which is interpreted as "excessive control and not being restricted and disobedience to social rules".

Finally, L and F scale are different for female who obtained and failed to obtain the right to register to both departments. As for the clinical tests, only masculinity - femininity (Mf) is different.

\section{References}

Ceyhun, B. \& Oral, N. (1998). MMPI Değerlendirme Kitabı. Ankara: Bilimsel Tip Yayınevi.

Çetingüç, M. (1995). Pilot Seçiminde Psikolojik Uygunluk Değerlendirmesi. Havacılık Tibbi El Kitabı. Eskişehir.

Dahlstrom, W.G. \& Welsch, G.S. (1975). An MMPI Hand Book: A Quide to Use in Clinical Practice and Research. MMPI Değerlendirme Kitabı içinde. Ceyhun, B. ve Oral, N. Ankara: Bilimsel Tip Yay1nevi.
Dahlstrom, W.G.; Welsch, G.S; Dahl Stom, E. (1972). An MMPI Hand Book: Vol. I Clinical Interpretation. Minnesota Pres. MMPI Değerlendirme Kitabı içinde. Ceyhun, B. ve Oral, N. Ankara: Bilimsel Tip Yayınevi.

Hathaway, S.R.; McKinley, J.C. (1967). Minnesota Multiphasic Personality Invantory Manuel. MMPI Değerlendirme Kitabı içinde. Ceyhun, B. ve Oral, N. Ankara: Bilimsel Tip Yayınevi.

Hunsley, J.; Hathaway, S.R.; McKinley, J.C. (1988). Minnesota Multiphasic Personality Inventory Manuel. MMPI Değerlendirme Kitabı içinde. Ceyhun, B. ve Oral, N. Ankara: Bilimsel Tip Yayınevi.

Jones, D.R. (1985). Psychiatry for Flying Surgeon. USAF Aerospace Medicine Primary Course-AMP. HO. 322.

Savaşır, I. (1981). Minnesota Çok Yönlü Kişilik Envanteri El Kitabı (Türk standardizasyonu). Ankara: Sevinç Matbaası.

Sharma, A., Malik, H. (2002). Human Factors in Helicopter and Transport Aircrafts in IAF. Indian Jurnal of Aerospace Med. 46 (1): 7-14.

Spohd, G. O. (1982). Human Factors Aspects of Aircraft Accidents. AGARD Lecture Series No: 125. (Presented on 8-9 November 1982 in Ankara, Turkey).

Trump, D.W. (1988). Medical Standarts for Civilian Aircrew. Aviation Medicine. Second edition. Edited By: Ernsting, J. \& King, P. London: Butterworths

Whitton, R. C. (1984). Medical Disqualification in USAF Pilots and Navigators. Aviation Space Environment Med. 55 (4):332-336. 